\title{
Do negative screening test results cause false reassurance? A systematic review
}

DOI:

10.1111/bjhp. 12265

\section{Document Version}

Accepted author manuscript

Link to publication record in Manchester Research Explorer

\section{Citation for published version (APA):}

Cooper, G., Harvie, M., \& French, D. (2017). Do negative screening test results cause false reassurance? A systematic review. British Journal of Health Psychology, 22(4), 958-977. https://doi.org/10.1111/bjhp.12265

\section{Published in:}

British Journal of Health Psychology

\section{Citing this paper}

Please note that where the full-text provided on Manchester Research Explorer is the Author Accepted Manuscript or Proof version this may differ from the final Published version. If citing, it is advised that you check and use the publisher's definitive version.

\section{General rights}

Copyright and moral rights for the publications made accessible in the Research Explorer are retained by the authors and/or other copyright owners and it is a condition of accessing publications that users recognise and abide by the legal requirements associated with these rights.

\section{Takedown policy}

If you believe that this document breaches copyright please refer to the University of Manchester's Takedown Procedures [http://man.ac.uk/04Y6Bo] or contact uml.scholarlycommunications@manchester.ac.uk providing relevant details, so we can investigate your claim.

\section{OPEN ACCESS}




\section{British Journal of Health Psychology \\ Do negative screening test results cause false reassurance? A systematic review --Manuscript Draft--}

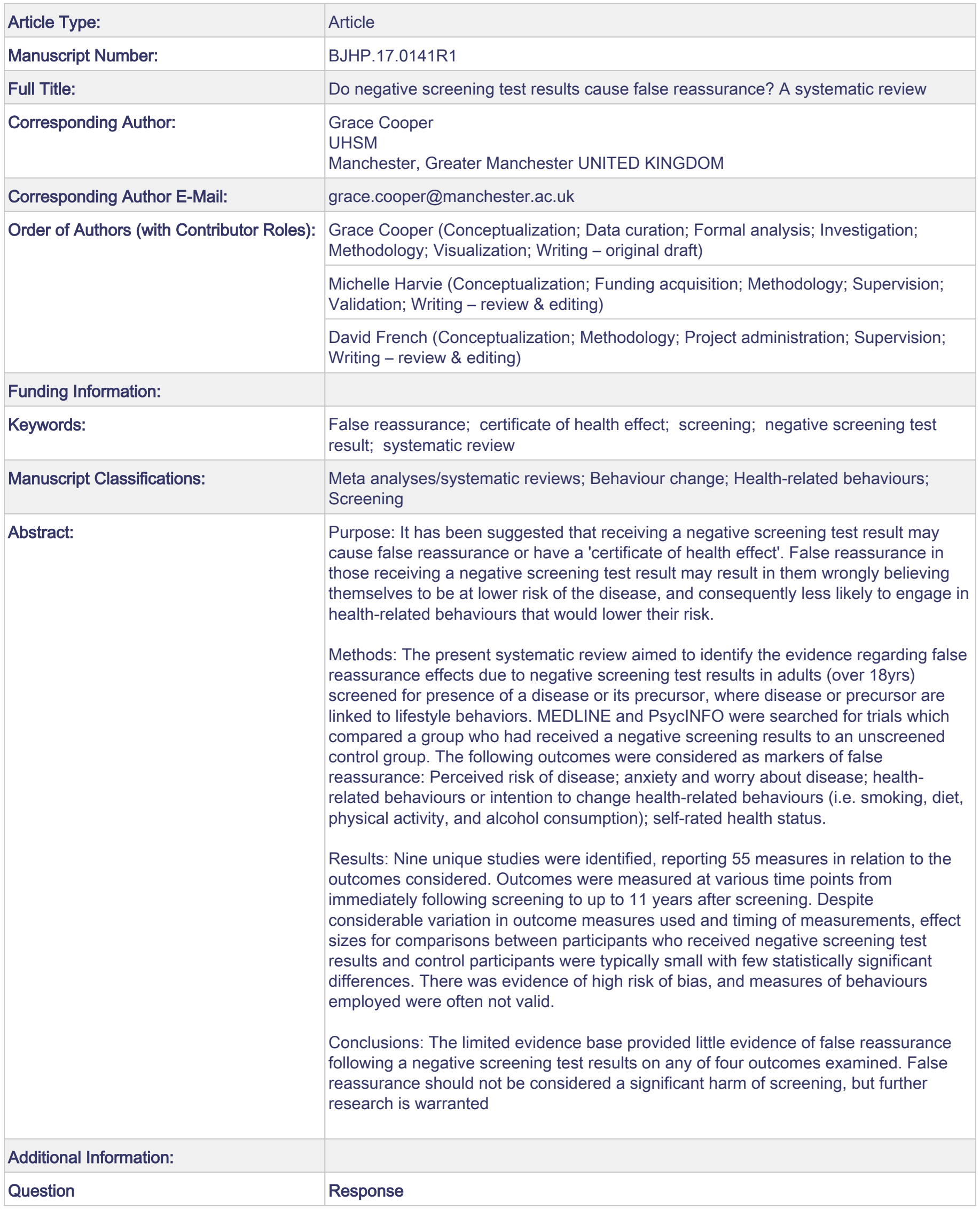


If you have any potentially competing

none

interests to declare, please enter them in the box below. If you have no interests to declare, please enter 'none'. Please declare any financial relationships (such as employment, consultancies, stock ownership or options, honoraria, patents, paid expert testimony) or any personal relationships which could be perceived to undermine the credibility of your research. By conflict of interest, we are referring to cases where professional judgment in relation to the research, or the welfare of research participants, may be influenced by another interest, such as financial gain or personal relationships.

Does this submission have any links or

none overlap with any other submitted or published manuscripts, for this or any other publication? (For example; as part of a long-term project, using a shared data set, a response to, or extension of, earlier work.) If yes, please give brief details. If no, please enter 'none'. Any overlap not declared and later discovered will result in the manuscript being withdrawn from consideration.

Please specify the word count of your manuscript (excluding the abstract, tables, figures and references).

Do you use Twitter for academic yes purposes? (If you do and your paper is accepted, we will 'mention' you when we share a link to the online article.)

What is your Twitter handle? as follow-up to "Do you use Twitter for academic purposes? (If you do and your paper is accepted, we will 'mention' you when we share a link to the online article.)" 
Thank you for these reviews which have raised important issues. We have addressed these comments and feel it has improved the paper considerably.

\section{Reviewer \#1:}

In 'statement of contribution' - first bullet point: either remove '(erroneously)' or change to 'negative test result, erroneously' as at present the sentence could be misinterpreted as an erroneous test result.

The word erroneously has been removed.

lines 64-66: this appears to be the conclusion to this review - if know prior to review, then why is the review necessary?

This has been reworded, to make it clearer and to avoid prejudging the results of the review. Prior reviews have only considered screening group as a whole and have not considered the negatively screed group separately (lines 69-77)

lines 104-105: how often did you contact the authors and find the detail was not available?

This information has been added to text and PRISMA flowchart. The authors of two studies which met the inclusion criteria but did not report the specified outcomes were contacted. One author provides additional information and this study was included in the review the second author failed to respond (Lines 114-117).

line 106: how was the data extracted and how many researchers extracted the data?

This information has been added. The data needed to calculate effect sizes were extracted and analysed by one author before being independently review by a second author (lines118-119).

line 86: typo? Negative rather than negatively?

This has been corrected (line 98)

line 209: add reference - Collins et al 2011?

This reference has been added (line 223)

lines 222-225 seems repetitive of lines 156-158

Details have been removed in lines 156-158 and included more appropriately in the discussion section (now lines 223-230). 


\section{Reviewer \#2:}

Introduction:

The introduction reads well. The authors provide a clear overview of screening and the potential implications of receiving a negative screen result. I have some minor comments:

1.Page 3 , line 46: 'the majority of people will screen negative...' If data is available, could the authors provide a percentage figure for the number of people who screen negative?

The following text has been added in lines 46-50 to demonstrate this; For example in the NHS breast screening programme, one of the most well established screening programmes in the UK $96 \%$ of participants receive a negative screening test result. Thought the exact number of negative results varies depending on various factors such as; the population being screened, the disease being screened for and the chosen screening procedure

2. Page 3 , lines 61 : 'has been indicated' is this a typo?

This has been changed to 'has been demonstrated' to make the statement clearer. (Line 64)

3. Page 3, lines 64-66: Could this sentence be rephrased so 'false reassurance' is not repeated? Please could the authors also provide a reference for this statement?

This has been rephrased and appropriate references added (lines 69-77).

4. In the Discussion (page 8-10, lines 185-226), the authors discuss and cite numerous reviews of false reassurance, but do not mention these in the introduction. I think the introduction could be strengthened with a short summary of these reviews, followed by a line which identifies the gap and reason for conducting this review.

More details of these reviews have been added to the introduction (lines 69-84), and the discussion has been shortened by removing these details.

Methods:

5. Page 4, line 86: Should this read '...those receiving a negative screen test'?

Yes as indicated this now read 'those receiving a negative screen test' (lines 97-98)

6. Page 4, line 87: Do the authors mean controls who were not screened? If so, please could this be clarified?

This has reworded to make it clear that controls had not received screening(line 98).

7. Page 4, lines 87-90: I assume this list of reported measures were selected as they can be used as proxy measures for false reassurance. Please could the authors provide a statement to clarify this for the reader either in the methods section or in the final paragraph of the introduction?

More detail has been added to introduction to make this clearer (lines 64-67 and lines 99-103) 


\section{Analysis section is missing}

Analysis heading has been added, and the relevant text from the results moved to this section (lines130 -137)

Results:

9. Page 5, lines 111-114: Please could the authors precede all the numbers in brackets with ' $n=$ ' e.g. 'studies screened for diabetes $(n=3)$ '.

These have been added (123-125).

10. Page 5, line 117: If all studies had high risk of bias, why were they included in the review?

In line with Cochrane guidance, all studies should be included in systematic reviews, and not omitted on basis of study quality. Risk of bias was mostly unavoidable due to a lack of blinding which would not be possible in these studies. Bias was also due to self-reported measures such as questionnaires which were usually appropriate for the measurements being taken. By highlighting these sources of bias, we flag up where future research in this area could be improved.

11. Page 6, lines 119-125: This section would be better placed in the 'analysis section' of the Methods

This is now induced in the analysis section (lines130-137).

12. Page 6, line 127: Could the authors replace the word 'overwhelming' with a numerical figure?

The word overwhelming has been removed and the number given under each outcome heading

13. Page 6, lines 127-140: This section would benefit from being broken down into four sub-sections in line with each of the four outcome measures. This results section also seems fairly brief and in places I found it difficult to understand the direction or effect of a negative screening result on each outcome. For instance on lines 132-134, two studies found a significant difference in terms of anxiety or worry- so did a negative screening test result in this case mean that p's were more anxious/worried or less anxious/worried after the negative screen result? Please could this be clarified with some additional text for this statement and all other statements in this section to provide some level of interpretation?

Heading for each outcome have been added and the direction of significances clarified (lines 104163).

14. References for the studies discussed in this section are missing

References have been added as foot notes to the tables to clarify which results are from which study. The references are also included in the reference list

Discussion:

I found the discussion difficult to follow in places. I think the Discussion would benefit from some revision, restructuring and perhaps shortening so the key messages stand out to the reader. I have a few suggestions for how this could be done: 
15. Page 7, lines 146-149: Could this sentence be rephrased to focus on the key headline finding?

This sentence has been rephrased (lines 169-170)

16. Page 7, lines 151-155: This study should be discussed in the results section

This has been moved to the results section (Lines 156-163).

17. Page 7, lines 155-158: 'a larger proportion of screening participants were screen positive for at least one the conditions'- this is interesting but I'm not sure how relevant it is to the review as the review was about impact of negative screening results on self-rated health.

As described above in response to reviewer $1 \mathrm{~s}$ comment this has been removed and explained more clearly in lines 222-225 (now lines 323-330).

18. Page 8-10, lines 185-226: Please see my comment in the Introduction section (comment 4). I think this section would benefit from shortening. If the authors provide a brief overview of previous reviews in the Introduction, they can draw on these in the Discussion to briefly explain which findings were in line with their review and which were not. This can be followed by discussion around why their findings were/were not in line with previous review studies.

Details of previous reviews have been moved from the discussion to the introduction. Making the discussion clearer and more concise (lines 64-84).

19. Page 8-10, lines 185-226: Findings appear to be reported in the Discussion which were not reported in such depth in the Results section (see my comment number 13).

Findings moved to results section (Lines 156-163).

20. Page 9, line 207: Please could the authors reflect on what they think is atypical about this study?

The following information has been added as a possible explanation for this difference (lines 218221);

It's not clear why this study follows a different trend to all the other studies included in this review. One possible explanation for this could be related to the screening procedure itself. The NORCCAP study utilised flexible sigmoidoscopy as a means of screening for colorectal cancer, it is possible that the more invasive nature of this test could influences people belief in the reliability and validity of the outcome.

21. Page 10, lines 228-230: I wonder if the conclusion is slightly overstated considering all studies included were of high risk of bias?

The wording has been changed to avoid overstating the conclusion (lines 263-264).

22. Page 11, line 252: '...done at low cost and with validated measures'?

With validated measures has been added (line 266) 
Table 2: Numbered referencing with references in a footnote of the table would be useful to direct the reader to which study the outcome was measured and which study the figures have been extracted from.

An additional footnote has been added with references, which are also included in reference list at the end of the document. 
Do negative screening test results cause false reassurance? A systematic review

$$
\text { Grace C. Cooper }{ }^{1 *} \text {, Michelle N. Harvie }{ }^{1} \text {, David P. French }{ }^{2}
$$

${ }^{1}$ University Hospital of South Manchester NHS Foundation Trust, Southmoor Road, Wythenshawe, Manchester, M23 9LT.

${ }^{2}$ Manchester Centre of Health Psychology, School of Health Sciences, The University of Manchester, Oxford Road, Manchester, M13 9PL

* Corresponding Author: Miss G C Cooper. The Nightingale and Prevent Breast Cancer centre, University Hospital of South Manchester NHS Foundation Trust, Southmoor Road, Wythenshawe, Manchester, M23 9LT.

Phone:(+44) 1612914413

Fax: :(+44) 1612914421

Email:Grace.cooper@manchester.ac.uk 


\section{Statement of contribution}

What is already known on this subject?

- It has been argued that screening for disease may cause 'false reassurance' whereby those who receive a negative screening test result wrongly interpret their result as indicating they are less likely to develop the disease in the future.

- There is some evidence for false reassurance, but the relevant studies consider a range of diseases and possible indicators of false reassurance (i.e. risk perceptions, lifestyle behaviours, emotional outcomes and quality of life).

- For these reasons, it is currently unclear the extent to receive negative screening test results is likely to impact on participants' lifestyle behaviours, or other possible indicators of false reassurance

What does this study add?

- Current available evidence shows that negative screening test results are unlikely to cause false reassurance, and in particular are unlikely to have a negative impact on lifestyle behaviours.

- Given the limitations of the current evidence base in terms of number of studies and study quality, future research should continue to explore this issue, where this can be done at low cost. 


\title{
Do negative screening test results cause false reassurance? A systematic
}

\section{review}

\begin{abstract}
$\underline{\text { Abstract }}$
Purpose: It has been suggested that receiving a negative screening test result may cause false reassurance or have a 'certificate of health effect'. False reassurance in those receiving a negative screening test result may result in them wrongly believing themselves to be at lower risk of the disease, and consequently less likely to engage in health-related behaviours that would lower their risk.
\end{abstract}

Methods: The present systematic review aimed to identify the evidence regarding false reassurance effects due to negative screening test results in adults (over 18yrs) screened for presence of a disease or its precursor, where disease or precursor are linked to lifestyle behaviors. MEDLINE and PsycINFO were searched for trials which compared a group who had received a negative screening results to an unscreened control group. The following outcomes were considered as markers of false reassurance: Perceived risk of disease; anxiety and worry about disease; health-related behaviours or intention to change health-related behaviours (i.e. smoking, diet, physical activity, and alcohol consumption); self-rated health status.

Results: Nine unique studies were identified, reporting 55 measures in relation to the outcomes considered. Outcomes were measured at various time points from immediately following screening to up to 11 years after screening. Despite considerable variation in outcome measures used and timing of measurements, effect sizes for comparisons between participants who received negative screening test results and control participants were 
typically small with few statistically significant differences. There was evidence of high risk of bias, and measures of behaviours employed were often not valid.

Conclusions: The limited evidence base provided little evidence of false reassurance following a negative screening test results on any of four outcomes examined. False reassurance should not be considered a significant harm of screening, but further research is warranted.

\section{$\underline{\text { Keywords }}$}

False reassurance, certificate of health effect, screening, negative screening test result, systematic review

\section{$\underline{\text { Introduction }}$}

Screening programmes aim to find a disease or precursors to a disease early before overt symptoms develop. This allows early treatment and improves outcomes. However, there are potential harms of screening which should be taken into account when assessing the net benefit of screening. These include over-diagnosis leading to unnecessary treatment, false positives or false negatives, and discomfort or risk associated with the screening procedure (Raftery \& Chorozoglou, 2011). Screening programmes are also very costly, and some argue that money used to fund screening could reduce the burden of disease more if it was used for to fund primary prevention and treatment (Sackett \& Holland, 1975). The potential harms of screening should be assessed as well as the potential benefits when evaluating whether a screening programme is warranted. For example, in the UK the National Screening Committee (NSC) considers the likely balance of harms and benefits of potential screening programmes before they are recommended and implemented (Public Health England, 2015).

In any screening program the majority of people will screen negative (Wilson \& Jungner, 1968). For example in the NHS breast screening programme, one of the most well established 
screening programmes in the UK $96 \%$ of participants receive a negative screening test result (Marmot et al., 2013). Thought the exact number of negative results varies depending on various factors such as; the population being screened, the disease being screened for and the chosen screening procedure. It has been proposed that some people who receive negative screening test results will interpret their result as indicating they are less likely to develop the disease (Marteau, Kinmonth, Thompson, \& Pyke, 1996). This is a misconception as screening only identifies if a person currently has the condition or marker for the condition at the time of screening and does not provide information about a person's future risk of developing the disease. This interpretation of negative screening test results as being

informative about future disease risk has been described as "false reassurance" or a

“certificate of health effect" (Larsen, Grotmol, Almendingen, \& Hoff, 2007; Marteau et al., 1996). The main practical implication of false reassurance is that this misconception may result in people who receive negative screening test results being less likely to engage in behaviours to reduce their risk of disease (Larsen et al., 2007; Marteau et al., 1996). This is highly relevant to most screening programme which mainly screen for diseases which are strongly linked to lifestyle factors, such as smoking and lack of physical activity.

It has also been argued that false reassurance has been demonstrated in, reports of lower anxiety or worry about the disease screened for (Marteau et al., 1996; van der Aalst, van den Bergh, Willemsen, de Koning, \& van Klaveren, 2010) and higher self-rated health (Eborall et al., 2007) in those receiving negative screening test results.

Previous systematic reviews have compared differences in health-related behaviours between participants who had been offered screening with control participants (Deutekom et al., 2010). However, authors were unable to draw conclusion due to a lack of studies. A separate 
systematic review by Collins, Lopez and Marteau (2011) compared emotional outcomes in participants who had been offered screening with control participants and concluded that screening had no impact on anxiety, depression and quality of life beyond four weeks after screening. These previous reviews have focussed only on the effects of all screening attendees, to be able to draw conclusions about the overall net effect of screening, and have not consider the negatively screened group separately to the whole screening population.

Given this, we conducted a systematic review to assess whether receiving a negative screening test result causes false reassurance. We specifically examined the available evidence of the impact of receiving a negative screening result on: Perceived risk of disease; Anxiety and worry about disease; Lifestyle behaviours or intention to change lifestyle behaviours including smoking, diet, weight, physical activity, and alcohol consumption; Selfrated health.

\section{$\underline{\text { Methods }}$}

Search strategy. MEDLINE and PsycINFO, were searched up to May 2016, with a search strategy based on key review papers (Collins, Lopez, \& Marteau, 2011; Deutekom et al., 2010) (see appendix 1) and adjusted for each database. Forward and backward citation searches from included articles and the key review papers (Collins et al., 2011; Deutekom et al., 2010) were conducted.

Inclusion and exclusion criteria. Randomised controlled trials which compared population based screening of asymptomatic adults (over 18 years) with no screening controls were eligible. Screening programmes were included if they screened for diseases linked to lifestyle behaviours such as type 2 diabetes, cancer (breast, bowel, cervical, lung), or 
abdominal aortic aneurysm. We included only studies which reported results for those receiving a negative screen test versus a control group who did not undergo screening. Included papers reported on one or more of the following markers of false reassurance:

Perceived risk of disease; Anxiety and worry about disease; Lifestyle behaviours or intention to change lifestyle behaviours including smoking, diet, weight, physical activity, and alcohol consumption; Self-rated health. For the lifestyle behaviour outcome we also included weight and BMI, due to the poor quality of many self-report diet measures .

We excluded unpublished literature and papers not available in English, as well as papers which communicated disease risk assessment i.e. where there is no negative test result for a condition but participants were told their future risk of developing a disease, e.g. Q Risk for cardiovascular disease (Hippisley-Cox, Coupland, \& Brindle, 2017).

Identification of relevant studies. Electronic searching identified 347 unique results.

Titles and abstracts of the papers were assessed for potential eligibility by two researchers independently, with a satisfactory level of agreement $(k a p p a=0.7)$. Discrepancies were settled by discussion and consensus amongst all three study authors. The full text papers were obtained for all papers deemed potentially relevant. The authors of two studies which met the inclusion criteria but did not report the specified outcomes were contacted. One author provides additional information and this study was included in the review the second author failed to respond. The final set of studies to be included was agreed following discussion by all three authors. The data needed to calculate effect sizes were extracted and analysed by one author before being independently review by a second author. We assessed risk of bias amongst the selected studies using the Cochrane Risk of Bias Tool (Higgins \& Green, 2011). 
122 Ten papers were identified, describing eight unique studies (see table 1 for a summary of 123 study characteristics). Studies screened for diabetes $(n=3)$, abdominal aortic aneurysm $(n=1)$, and cancer (lung cancer $[\mathrm{n}=2]$ colorectal $[\mathrm{n}=1]$ and multiple cancers $[\mathrm{n}=1]$ ). Studies were based in the UK $(n=3)$, Netherlands $(n=2)$, USA $(n=2)$, Norway $(n=1)$ and Denmark $(n=1)$. Study sample sizes were typically large, varying from $N=278$ to $N=14012$. Outcomes were measured at various time points from immediately following screening to up to 11 years after screening. All the included studies had high risk of bias from a number of sources (see appendix 2).

Analysis. Difference in how outcomes were measured and the time points at which they were measured between the studies meant that meta-analysis was not appropriate. For example, there were 10 different measures of diet quality, and six each for smoking status or physical activity. (for full details see appendix 3). Given this heterogeneity, results were tabulated to show the effect sizes and results of statistical significance tests for comparisons between participants who received negative screening test results compared with control participants across the studies (see table 2).

\section{$\underline{\text { Results }}$}

Perceived risk of disease. Of the seven measures of disease risk perception, only two were statistically significant. In both these cases the effect size was small $(-0.16<$ Standardised mean difference $(\mathrm{SMD})<-0.01)$, indicating that only in these two cases did a negative screening test results result in a small decrease in perceived risk of the disease screened for. 
Anxiety and worry about disease. There were nine tests assessing if participants

who received negative screening test results or control participants differed in terms of anxiety or worry. Only two of these nine were statistically significant indicating lower levels of anxiety or worry in the screen negative group however both were of small effect $(-0.22<$ $\operatorname{SMD}<0.06)$.

Lifestyle behaviours or intention to change lifestyle behaviours. Of 28 tests of whether participants who received negative screening test results or control participants differed in reports of health-related behaviours or intention to change behaviour only five showed a statistically significant unfavourable change in the negatively screened groups health related behaviours or intention to change their behaviour. The NORCCAP (Berstad et al., 2014) study of colorectal screening was responsible for all of these significant results suggesting that in this trial, negative screening test results had a detrimental effect on lifestyle behaviours that were apparent at three years post-screening As observed with all outcomes, the effect sizes were consistently small $(-0.11<\mathrm{SMD}<0.17 ; 0.74<\mathrm{OR}<1.1)$. The largest effects came in relation to self-reported health $(-0.55<\mathrm{SMD}<0.14 ; \mathrm{OR}=1.1)$, but even there, none of 11 tests comparing those received negative screening test results with control participants were statistically significant. 


\section{$\underline{\text { Discussion }}$}

Across a variety of diseases screened for, countries, measures of false reassurance and duration of measurement since screening, there was little evidence of false reassurance or a negative impact on lifestyle behaviours. Effect sizes for comparisons between participants who received negative screening test results and control participants were typically small with few statistically significant differences. This lack of statistical significance is notable because of the very large samples sizes employed in these studies. There were two studies which deviated from this otherwise consistent pattern of results. The NORCCAP (Berstad et al., 2014; Larsen et al., 2007) study of colorectal screening was responsible for all five of the significant results obtained. The largest effect sizes in the review were found in the PLCO trial (Taylor, Shelby, Gelmann, \& McGuire, 2004).

The present systematic review aimed to provide a comprehensive assessment of false reassurance by including four indicators of false reassurance. To achieve this aim, we searched using multiple databases and used forward and backward citation searching to identify relevant literature. However, we did not include unpublished literature or studies published in languages other than English. Further, given that the studies included in this review were not specifically design to examine false reassurance, it is possible that other eligible studies may have been missed due to searches being unlikely to pick up all such studies. It is also likely that other studies collected data that would have been eligible for the present review, and may even have been analysed, but not published due to the general tendency of non-significant result to not be reported (Hopewell, Loudon, Clarke, Oxman, \& Dickersin, 2009). 
The primary studies included in this review had complete data and good follow-up, even many years following screening which further adds strength to these findings (see table one). However, all the included studies had high risk of bias from several sources (see appendix 2). Blinding of participants to the intervention was not possible resulting in a high risk of performance bias, and most of the outcome data was collected via a participant completed questionnaire resulting in a high risk of detection bias. Response rates in the control group were generally lower than in the screening groups, leading to a high risk of attrition bias. In addition, although anxiety and worry and self-rated health were assessed using validated scales, behavioural outcomes were typically measured using unvalidated scales, often with self-reported measures. Further, the wide variety of scales across all outcomes made it difficult to synthesise results across studies, as did the variety of assessment time points.

The present results are broadly in agreement with previous systematic reviews which compared participants who had been offered screening with control participants (Collins et al., 2011; Deutekom et al., 2010) his agreement is notable given that both previous reviews focussed on the effects of all screening attendees,. The similarity of the results of the previous reviews and the present review probably reflects the fact that in most screening programmes, most people receive negative screening test results.

The review by Deutekom et al., 2010 found two eligible RCTs of the effects of screening on health behaviours, only one of which is included in the present review as the other study was concerned with screening for hearing loss. In the present review, five studies provided 28 tests of whether participants who received negative screening test results or control participants differed in reports of health-related behaviours or intention to change behaviour only five were statistically significant, with consistently small effect sizes. It is notable that 
the five significant results all came from the NORCCAP (Berstad et al., 2014; Larsen et al., 2007) study of colorectal screening. It's not clear why this study follows a different trend to all the other studies included in this review. One possible explanation for this could be related to the screening procedure itself. The NORCCAP study utilised flexible sigmoidoscopy as a means of screening for colorectal cancer, it is possible that the more invasive nature of this test could influences people belief in the reliability and validity of the outcome.

The previous review of emotional outcomes (Collins et al., 2011) identified 12 eligible studies, and concluded that screening had no impact on anxiety, depression and quality of life beyond four weeks after screening. In the present review, two out of nine tests showed statistically significant differences in anxiety or worry in participants who received negative screening test results compared to control participants with consistently small effect sizes. This provides some support for the idea that receiving negative screening test results may reduce anxiety or worry, a result that is in line with the common finding that people attend screening in order to receive reassurance (Saidi, Sutton, \& Bickler, 1998). In the present review, the largest effects came in relation to self-reported health, but even there, none of 11 tests comparing those received negative screening test results with control participants were statistically significant. The largest effect sizes for self-rated health in the present review were found for the PLCO (Taylor et al., 2004) study of screening for four conditions (prostate, lung, colorectal and ovarian cancers), in contrast to all other studies in the present review, which screened for a single condition. In the PLCO (Taylor et al., 2004) study, a high proportion of screening participants were screen positive for at least one of the conditions, which may indicate why those who screened negative for all conditions showed a comparatively large effect on self-rated health, with the caveat that the effects were not significant as the sample size was small for this study. 
241 The available evidence in the present review suggests that concerns about false reassurance

with negative screening test results appear overstated and is unlikely to be a major harm of screening for any of the four outcomes examined. Across a range of conditions screened for in a variety of counties and populations overwhelmingly the studies contained in this review do not find evidence of false reassurance.

It should be noted that there remains considerable uncertainty around the conclusion that false reassurance is not a major harm of screening. There are several limitations of the present evidence base: few studies, which lack a priori planned analyses in relation to false reassurance, which have high risk of bias, which use often unvalidated single item measures, and which employ different measures in each study, making it problematic to aggregate findings.

Given this, future studies to examine the effects of screening programmes should include a priori planned analyses of false reassurance. This could be most suitable for studies assessing the effectiveness and cost effectiveness of either new screening programs or when existing ones are introduced into new populations. Such studies should use validated measures of false reassurance and lifestyle behaviour change and should aim to use the same measures as those employed in studies in this review, where possible, to allow accumulation of knowledge.

\section{Conclusion}

Current available evidence shows that negative screening results are unlikely to cause false reassurance, and in particular are unlikely to have a negative impact on lifestyle behaviours. However, given the numerous limitations of the current evidence base future research should 
continue to explore this issue, where this can be done at low cost and with validated 266 measures. 


\section{$\underline{\text { References }}$}

Ashraf, H., Tonnesen, P., Holst Pedersen, J., Dirksen, A., Thorsen, H., \& Dossing, M. (2008). Effect of CT screening on smoking habits at 1-year follow-up in the Danish Lung Cancer Screening Trial (DLCST). Thorax, 64(5), 388-392. doi: 10.1136/thx.2008.102475

Berstad, P., Løberg, M., Larsen, I. K., Kalager, M., Holme, Ø., Botteri, E., . . Hoff, G. (2014). Long-term lifestyle changes after colorectal cancer screening: Randomised controlled trial. Gut, 64(8), 1268-1276. doi: 10.1136/gutjnl-2014-307376

Collins, R. E., Lopez, L. M., \& Marteau, T. M. (2011). Emotional impact of screening: A systematic review and meta-analysis. BMC Public Health, 11(1). doi: 10.1186/14712458-11-603

Deutekom, M., Vansenne, F., McCaffery, K., Essink-Bot, M. L., Stronks, K., \& Bossuyt, P. M. M. (2010). The effects of screening on health behaviour: A summary of the results of randomized controlled trials. Journal of Public Health, 33(1), 71-79. doi: 10.1093/pubmed/fdq050

Eborall, H. C., Griffin, S. J., Prevost, A. T., Kinmonth, A. L., French, D. P., \& Sutton, S. (2007). Psychological impact of screening for type 2 diabetes: controlled trial and comparative study embedded in the ADDITION (Cambridge) randomised controlled trial. BMJ, 335(7618), 486-486. doi: 10.1136/bmj.39303.723449.55

Higgins, J., \& Green, S. (Eds.). (2011). Cochrane handbook for systematic reviews of interventions: Cochrane book series (Version 5 ed.). Chichester, England: John Wiley \& Sons.

Hippisley-Cox, J., Coupland, C., \& Brindle, P. (2017). Development and validation of QRISK3 risk prediction algorithms to estimate future risk of cardiovascular disease: prospective cohort study. BMJ, 357. doi: 10.1136/bmj.j2099

Hopewell, S., Loudon, K., Clarke, M. J., Oxman, A. D., \& Dickersin, K. (2009). Publication bias in clinical trials due to statistical significance or direction of trial results. Cochrane Database of Systematic Reviews, (1). doi:10.1002/14651858.mr000006.pub3

Larsen, I. K., Grotmol, T., Almendingen, K., \& Hoff, G. (2007). Impact of Colorectal Cancer Screening on Future Lifestyle Choices: A Three-Year Randomized Controlled Trial. Clinical Gastroenterology and Hepatology, 5(4), 477-483. doi: 10.1016/j.cgh.2006.12.011

Marmot, M. G., Altman, D. G., Cameron, D. A., Dewar, J. A., Thompson, S. G., \& Wilcox, M. (2013). The benefits and harms of breast cancer screening: an independent review. [Review]. Br J Cancer, 108(11), 2205-2240. doi: 10.1038/bjc.2013.177

Marteau, T. M., Kinmonth, A. L., Thompson, S., \& Pyke, S. (1996). The psychological impact of cardiovascular screening and intervention in primary care: $A$ problem of false reassurance? British family heart study group. The British journal of general practice : the journal of the Royal College of General Practitioners., 46(411), 577-582.

Moshfegh, A. J., Rhodes, D. G., Baer, D. J., Murayi, T., Clemens, J. C., Rumpler, W. V., . . Cleveland, L. E. (2008). The US department of agriculture automated multiple-pass 
method reduces bias in the collection of energy intakes. The American journal of clinical nutrition., 88(2), 324-332.

Paddison, C. A. M., Eborall, H. C., Sutton, S., French, D. P., Vasconcelos, J., Prevost, A. T., . .. Griffin, S. J. (2009). Are people with negative diabetes screening tests falsely reassured? Parallel group cohort study embedded in the ADDITION (Cambridge) randomised controlled trial. BMJ, 339 (nov30), b4535 doi: 10.1136/bmj.b4535

Park, P., Simmons, R. K., Prevost, A. T., \& Griffin, S. J. (2008). Screening for type 2 diabetes is feasible, acceptable, but associated with increased short-term anxiety: $A$ randomised controlled trial in British general practice. BMC Public Health, 8(1), 350. doi: 10.1186/1471-2458-8-350

Public Health England. (2015). Criteria for appraising the viability, effectiveness and appropriateness of a screening programme, from https://www.gov.uk/government/publications/evidence-review-criteria-nationalscreening-programmes/criteria-for-appraising-the-viability-effectiveness-andappropriateness-of-a-screening-programme

Raftery, J., \& Chorozoglou, M. (2011). Possible net harms of breast cancer screening: updated modelling of Forrest report. BMJ, 343, d7627. Retrieved from doi:10.1136/bmj.d7627

Sackett, D. L., \& Holland, W. W. (1975). Controversy in the detection of disease. Lancet, 2(7930), 357-359.

Saidi, G., Sutton, S., \& Bickler, G. (1998). A predictive study of reasons for attendance and non-attendance at a breast screening programme. Psychology \& Health, 13(1), 2333. doi: $10.1080 / 08870449808406128$

Scott, R. A. P. (2002). The Multicentre Aneurysm Screening Study (MASS) into the effect of abdominal aortic aneurysm screening on mortality in men: a randomised controlled trial. The Lancet, 360(9345), 1531-1539. doi: 10.1016/s0140-6736(02)11522-4

Taylor, K. L., Shelby, R., Gelmann, E., \& McGuire, C. (2004). Quality of Life and Trial Adherence Among Participants in the Prostate, Lung, Colorectal, and Ovarian Cancer Screening Trial. JNCI Journal of the National Cancer Institute, 96(14), 10831094. doi: 10.1093/jnci/djh194

van der Aalst, C. M., van den Bergh, K. A. M., Willemsen, M. C., de Koning, H. J., \& van Klaveren, R. J. (2010). Lung cancer screening and smoking abstinence: 2 year follow-up data from the Dutch-Belgian randomised controlled lung cancer screening trial. Thorax, 65(7), 600-605. doi: 10.1136/thx.2009.133751

Willems, J. I., Otto, S. J., Klijs, B., \& de Koning, H. J. (2013). Screening for Type 2 Diabetes in a High-Risk Population: Effects of a Negative Screening Test After 4 Years Followup. Annals of Behavioral Medicine, 47(1), 102-110. doi: 10.1007/s12160-013-9525-3

Wilson, J. M. G., \& Jungner, G. (1968). Principles and practice of screening for disease, Public Health Paper Number 34. Geneva: World Health Organization. 
353 1. Medline; *MASS SCREENING/; 45220 results.

354 2. Medline; *RISK ASSESSMENT/; 20729 results.

355 3. Medline; screen*. ti, ab; 527649 results.

356 4. Medline; 1 OR 2 OR 3; 527649 results.

357 5. Medline; (cancer OR diabetes OR aneurysm).ti,ab; 1618415 results.

358 6. Medline; ((self ADJ rated) AND health).ti,ab; 6084 results.

359 7. Medline; (Intention* AND change).ti, ab; 4886 results.

360 8. Medline; ((reassured OR reassurance)).ti,ab; 5137 results.

361 9. Medline; (percived OR perception).ti,ab; 114308 results.

362 10. Medline; SMOKING/; 127301 results.

363 11. Medline; DIET/; 127085 results.

364 12. Medline; BODY WEIGHT/; 168969 results.

365 13. Medline; (BMI OR "Body mass index").ti,ab; 158109 results.

366 14. Medline; ALCOHOL DRINKING/; 55163 results.

367 15. Medline; ("Physical activity" OR exersice).ti,ab; 67383 results.

368 16. Medline; 6 or 7 or 8 or 9 or 10 or 11 or 12 or 14 or 14 or $15 ; 195309$ results.

369 17. PsycInfo; SCREENING/; 9072 results.

370 18. PsycInfo; RISK ASSESSMENT/; 11216 results.

371 19. PsycInfo; screen*. ti, ab; 72746 results.

372 20. PsycInfo; 17 or 18 or $19 ; 72746$ results.

373 21. PsycInfo; (cancer OR diabetes OR aneurysm).ti, ab; 66681 results.

374 22. PsycInfo; 20 AND 21; 7041 results.

375 23. PsycInfo; ((self ADJ rated) AND health).ti,ab; 3677 results.

376 24. PsycInfo; (Intention* AND change).ti, ab; 4811 results.

377 25. PsycInfo; ((reassured OR reassurance)).ti,ab; 2402 results.

378 26. PsycInfo; (percived OR perception).ti,ab; 129372 results.

379 27. PsycInfo; TOBACCO SMOKING/; 25892 results.

380 28. PsycInfo; DIETS/; 10581 results.

381 29. PsycInfo; BODY MASS INDEX/; 4415 results.

382 30. PsycInfo; ALCOHOLIC BEVERAGES/; 1716 results.

383 31. PsycInfo; PHYSICAL ACTIVITY/; 14642 results.

384 32. PsycInfo; CLINICAL TRIALS/; 10155 results.

385 33. PsycInfo; (random* OR trial* OR group* OR placebo*). ti, ab; 905046 results.

386 34. PsycInfo; 22 and (26 or 24 or 25 or 26 or 27 or 28 or 29 or 30 or 34); 350 results.

387 35. PsycInfo; 34 [Limit to: (Language English) and (Age group Adulthood 18 Yrs \& 01der)

388 and (Population Human)];

389 36. Medline; PREGNANCY/; 766255 results.

390 37. Medline; 4 not $36 ; 502765$ results.

391 38. Medline; 5 AND 37; 95039 results.

392 39. Medline; 16 AND 38; 1877 results.

393 40. Medline; 39 [Limit to: (Document type Randomized Controlled Trial) and (Language

394 English) and (Age group

395 Adult) and Humans]; 92 results.

396 41. PsycInfo; 35 [Limit to: (Language English) and (Age group Adulthood 18 Yrs \&

397 01der) and (Population Human)]; 24 results.

398 42. Medline; 40 [Limit to: (Document type Randomized Controlled Trial) and

399 (Language English) and (Age group Adult) and Humans]; 7 results. 


\section{Appendix 2 Risk of bias table using the Cochrane Collaboration's tool for assessing risk of bias}

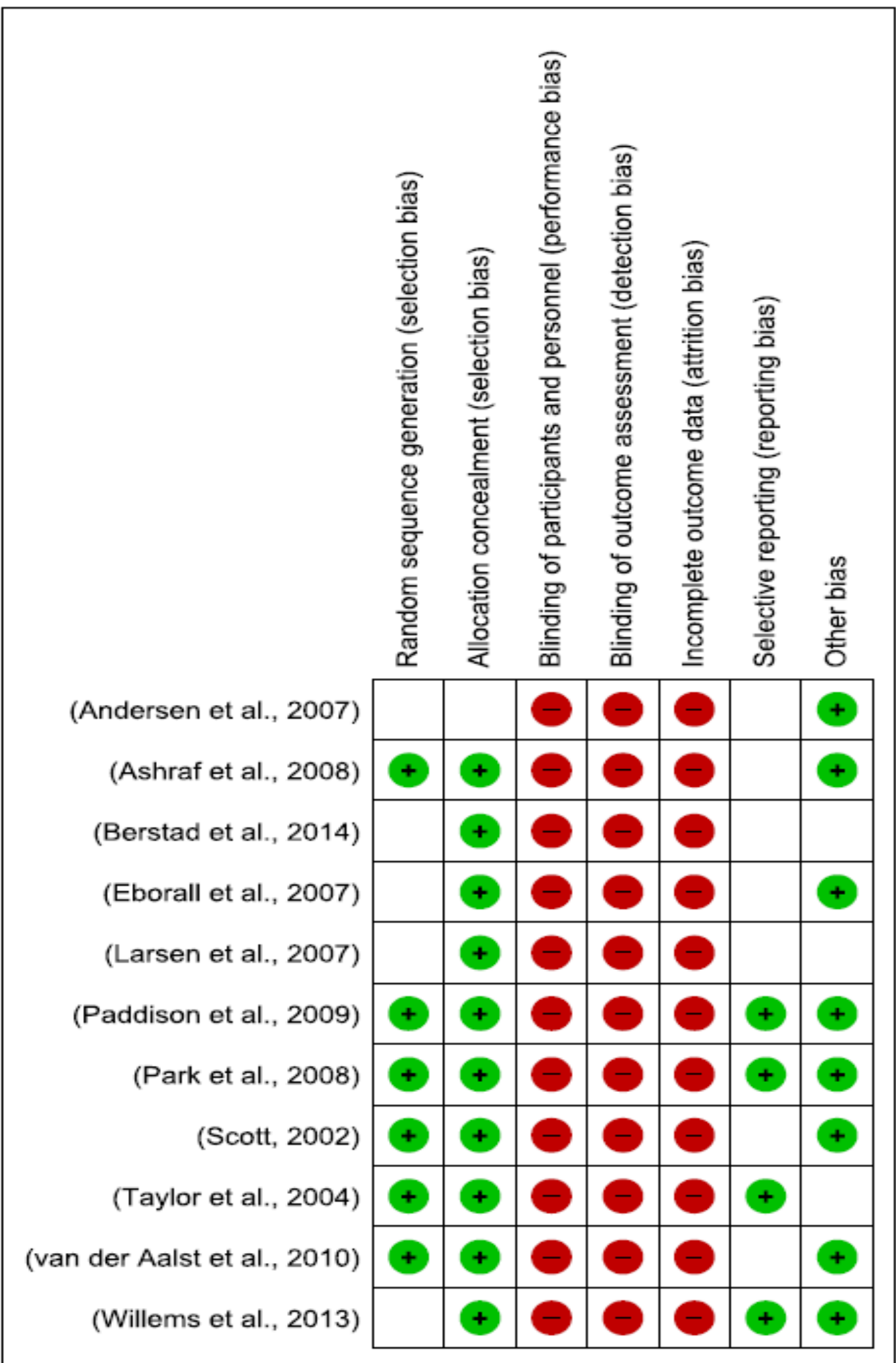




\section{Appendix 3 Full break down of results from each study and calculated effect sizes or odds ratio}

\section{Perceived risk of disease screened for}

\begin{tabular}{|c|c|c|c|c|c|}
\hline Measure & Description of measure & $\begin{array}{l}\text { Condition and } \\
\text { population }\end{array}$ & Study & $\begin{array}{l}\text { Time frame } \\
\text { after } \\
\text { screening }\end{array}$ & Effect size \\
\hline Personal risk & Percentage risk of developing diabetes in lifetime & $\begin{array}{l}\text { Diabetes Screening } \\
\text { Cambridge, east England, } \\
\text { UK }\end{array}$ & $\begin{array}{l}\text { ADDITION (Paddison } \\
\text { et al., 2009) }\end{array}$ & $\begin{array}{l}\text { Immediate } \\
\text { 3-6months } \\
\text { 12-15months }\end{array}$ & $\begin{array}{l}-0.08 \\
-0.01 \\
-0.3\end{array}$ \\
\hline $\begin{array}{l}\text { Comparative } \\
\text { risk }\end{array}$ & $\begin{array}{l}\text { Risk of developing diabetes compare to other the same } \\
\text { age: Much more likely/Much less likely scale }\end{array}$ & $\begin{array}{l}\text { Diabetes Screening } \\
\text { Cambridge, east England, } \\
\text { UK }\end{array}$ & $\begin{array}{l}\text { ADDITION (Paddison } \\
\text { et al., 2009) }\end{array}$ & $\begin{array}{l}\text { Immediate } \\
\text { 3-6months } \\
\text { 12-15months }\end{array}$ & $\begin{array}{l}-0.16^{*} \\
-0.02 \\
-0.1 \\
\end{array}$ \\
\hline $\begin{array}{l}\text { Perceived } \\
\text { risk }\end{array}$ & $\begin{array}{l}\text { Risk of developing diabetes compare to other the same } \\
\text { age: Much more likely/Much less likely scale }\end{array}$ & $\begin{array}{l}\text { Diabetes screening } \\
\text { Netherlands }\end{array}$ & (Willems et al., 2013) & 4 yrs & $-0.14^{*}$ \\
\hline
\end{tabular}

*Indicates $p<0.05$

Positive effect size indicates negative screen group > control (unscreened group) 


\section{Self-rated heath}

\begin{tabular}{|c|c|c|c|c|c|}
\hline Measure & $\begin{array}{l}\text { Description of } \\
\text { measure }\end{array}$ & Condition and population & Study & Time frame & $\begin{array}{l}\text { Effect size (Or odds } \\
\text { ratio where } \\
\text { appropriate) }\end{array}$ \\
\hline Self-rated health & $\begin{array}{l}\text { Excellent to } \\
\text { poor scale }\end{array}$ & $\begin{array}{l}\text { Diabetes Screening } \\
\text { Cambridge, east England, UK }\end{array}$ & $\begin{array}{l}\text { ADDITION (Paddison et al., } \\
\text { 2009) and (Eborall et al., 2007) }\end{array}$ & $\begin{array}{l}\text { Immediate } \\
\text { 3-6months } \\
\text { 12-15months }\end{array}$ & $\begin{array}{l}0.04 \\
0 \\
-0.06\end{array}$ \\
\hline $\begin{array}{l}\text { Self reported } \\
\text { health }\end{array}$ & $\begin{array}{l}\text { Scale improved } \\
\text { or not on follow } \\
\text { up }\end{array}$ & $\begin{array}{l}\text { Diabetes screening } \\
\text { Netherlands }\end{array}$ & (Willems et al., 2013) & $4 y r s$ & 0dds ratio 1.1 \\
\hline $\begin{array}{l}\text { EuroQol visual } \\
\text { acuity score }\end{array}$ & $\begin{array}{l}\text { Self rated health } \\
\text { scale } 0-100\end{array}$ & $\begin{array}{l}\text { Aneurysm screening } \\
\text { Portsmouth, Southampton, Winchester, } \\
\text { and Oxford, South England, UK }\end{array}$ & MASS (Scott, 2002) & 6 week & 0.05 \\
\hline $\begin{array}{l}\text { Mental health } \\
\text { summary score }\end{array}$ & SF-12 & $\begin{array}{l}\text { Prostate, lung, colorectal, ovarian } \\
\text { cancers screening. } \\
\text { Georgetown, Washington, USA }\end{array}$ & PLCO (Taylor et al., 2004) & Immediate & -0.55 \\
\hline $\begin{array}{l}\text { Mental health } \\
\text { summary score }\end{array}$ & SF-36 & $\begin{array}{l}\text { Aneurysm screening } \\
\text { Portsmouth, Southampton, Winchester, } \\
\text { and Oxford, South England, UK }\end{array}$ & MASS (Scott, 2002) & 6 week & 0.04 \\
\hline $\begin{array}{l}\text { mental health } \\
\text { summary score }\end{array}$ & SF-12 & $\begin{array}{l}\text { Prostate, lung, colorectal, ovarian } \\
\text { cancers screening. } \\
\text { Georgetown, Washington, USA }\end{array}$ & PLCO (Taylor et al., 2004) & 1year & -0.24 \\
\hline Physical health & SF-36 & $\begin{array}{l}\text { Prostate, lung, colorectal, ovarian } \\
\text { cancers screening. } \\
\text { Georgetown, Washington, USA }\end{array}$ & PLCO (Taylor et al., 2004) & Immediate & -0.27 \\
\hline Physical health & SF-36 & $\begin{array}{l}\text { Aneurysm screening } \\
\text { Portsmouth, Southampton, Winchester, } \\
\text { and Oxford, South England, UK }\end{array}$ & MASS (Scott, 2002) & 6 week & 0.07 \\
\hline Physical health & SF-36 & $\begin{array}{l}\text { Prostate, lung, colorectal, ovarian } \\
\text { cancers screening. Georgetown, } \\
\text { Washington USA }\end{array}$ & PLCO (Taylor et al., 2004) & 1year & 0.14 \\
\hline
\end{tabular}

*Indicates $p<0.05$

Positive effect size indicates negative screen group > control (unscreened group) 


\section{Anxiety and worry}

\begin{tabular}{|c|c|c|c|c|c|}
\hline Measure & $\begin{array}{l}\text { Description of } \\
\text { measure }\end{array}$ & Condition and population & Study & Time frame & Effect size \\
\hline $\begin{array}{l}\text { Worry about } \\
\text { diabetes }\end{array}$ & $\begin{array}{l}\text { Adapted Lerman } \\
\text { cancer worry scale } \\
\text { (score 6-24) }\end{array}$ & $\begin{array}{l}\text { Diabetes screening } \\
\text { Cambridge, East of England, UK }\end{array}$ & ADDITION(Eborall et al., 2007) & $\begin{array}{l}\text { Immediate } \\
3-6 \mathrm{~ms} \\
\text { 12-15months }\end{array}$ & $\begin{array}{l}0.01 \\
-0.09 \\
-0.22 *\end{array}$ \\
\hline Anxiety & State trait anxiety & $\begin{array}{l}\text { Diabetes screening } \\
\text { Cambridge, East of England, UK }\end{array}$ & ADDITION(Eborall et al., 2007) & $\begin{array}{l}\text { Immediate } \\
\text { 3-6ms } \\
\text { 12-15months }\end{array}$ & $\begin{array}{l}-0.03 \\
0.15^{*} \\
0.06\end{array}$ \\
\hline Anxiety & State trait anxiety & $\begin{array}{l}\text { Diabetes screening } \\
\text { Cambridge, East of England, UK (Different } \\
\text { GP practises from those in full ADDITION) }\end{array}$ & $\begin{array}{l}\text { ADDITION-Pilot (Park et al., } \\
\text { 2008) }\end{array}$ & 6 weeks & -0.06 \\
\hline Anxiety & State trait anxiety & $\begin{array}{l}\text { Aneurysm screening } \\
\text { Portsmouth, Southampton, Winchester, } \\
\text { and Oxford, South England, UK }\end{array}$ & MASS (Scott, 2002) & 6 weeks & -0.09 \\
\hline $\begin{array}{l}\text { Worry about } \\
\text { getting diabetes }\end{array}$ & $\begin{array}{l}\text { Symptoms risk } \\
\text { questionnaire }\end{array}$ & $\begin{array}{l}\text { Diabetes screening } \\
\text { Netherlands }\end{array}$ & (Willems et al., 2013) & $4 y r s$ & 0 \\
\hline
\end{tabular}

*Indicates $p<0.05$

Positive effect size indicates negative screen group > control (unscreened group) 


\section{Lifestyle behaviour and Intention to change lifestyle behaviour}

Smoking

\begin{tabular}{|c|c|c|c|c|c|}
\hline Measure & Description of measure & Condition and population & Study & Time frame & $\begin{array}{l}\text { Effect size (Or } \\
\text { odds ratio } \\
\text { where } \\
\text { appropriate) }\end{array}$ \\
\hline Smoking status & Smoker or non-smoker & $\begin{array}{l}\text { Diabetes screening } \\
\text { Netherlands }\end{array}$ & (Willems et al., 2013) & $4 y r s$ & $\begin{array}{l}\text { Odds ratio } \\
0.74\end{array}$ \\
\hline Smoking status & $\begin{array}{l}\text { 1-6 scale: Never( } 1) \text {, former (2), } \\
\text { occasional(3), } 1-10 \text { day }(4), 11-20 \\
\text { day }(5), \text { more than } 20 / \text { day }(6)\end{array}$ & Colorectal cancer screening & NORCCAP (Larsen et al., ) & 3 yrs & $0.07 *$ \\
\hline Cigarettes per day & $\begin{array}{l}\text { Continuous smokers at baseline } \\
\text { Recent quitters at baseline }\end{array}$ & $\begin{array}{l}\text { Lung cancer screening } \\
\text { Copenhagen, Denmark }\end{array}$ & DLCST (Ashraf et al., 2008) & $1 \mathrm{yr}$ & $\begin{array}{l}\text { Odds ratio } \\
1.1 \\
1.00\end{array}$ \\
\hline $\begin{array}{l}\text { Prolonged smoking } \\
\text { abstinence }\end{array}$ & $\begin{array}{l}\text { Smoked less than } 5 \text { cigarettes in } 2 \\
\text { weeks after quit date }\end{array}$ & $\begin{array}{l}\text { Lung cancer screening } \\
\text { Rotterdam, Netherlands }\end{array}$ & $\begin{array}{l}\text { NELSON (Van der Aalst., } \\
\text { 2010) }\end{array}$ & 2 yrs & $\begin{array}{l}\text { Odds ratio } \\
0.86\end{array}$ \\
\hline Smoking & Percentage who currently smoke & $\begin{array}{l}\text { Colorectal cancer screening } \\
\text { Telemark and Oslo, Norway }\end{array}$ & $\begin{array}{l}\text { NORCCAP(Berstard et al } \\
\text { 2014) }\end{array}$ & 11years & 0.02 \\
\hline
\end{tabular}

*Indicates $p<0.05$

Positive effect size indicates negative screen group > control (unscreened group) 


\begin{tabular}{|c|c|c|c|c|c|}
\hline Measure & Description of measure & Condition and population & Study & Time frame & $\begin{array}{l}\text { Effect } \\
\text { size }\end{array}$ \\
\hline $\begin{array}{l}\text { Servings of fruit and } \\
\text { vegetables/day }\end{array}$ & $\begin{array}{l}\text { 1-6 scale: never to more } \\
\text { than } 3 \text { servings /day }\end{array}$ & $\begin{array}{l}\text { Colorectal cancer screening } \\
\text { Telemark and Oslo, Norway }\end{array}$ & NORCCAP(Larsen et al., 2007) & 3 yrs & $-0.04 *$ \\
\hline $\begin{array}{l}\text { Servings of fruit and } \\
\text { vegetables/day }\end{array}$ & $\begin{array}{l}\text { Number of serving per } \\
\text { day. }\end{array}$ & $\begin{array}{l}\text { Colorectal cancer screening } \\
\text { Telemark and Oslo, Norway }\end{array}$ & NORCCAP(Berstard et al 2014) & 11years & -0.08 \\
\hline $\begin{array}{l}\text { Consumption of meat(not } \\
\text { poultry or fish) for dinner }\end{array}$ & Servings per day & $\begin{array}{l}\text { Colorectal cancer screening } \\
\text { Telemark and Oslo, Norway }\end{array}$ & NORCCAP(Berstard et al 2014) & 11years & 0.04 \\
\hline Consumption of fatty fish & Servings per day & $\begin{array}{l}\text { Colorectal cancer screening } \\
\text { Telemark and Oslo, Norway }\end{array}$ & NORCCAP(Berstard et al 2014) & 11years & -0.04 \\
\hline Intention to reduce fat intake & $\begin{array}{l}5 \text { point Agreement scale } \\
1 \text { strongly disagree - } 5 \\
\text { strongly agree }\end{array}$ & Diabetes Screening & ADDITION (Paddison et al., 2009) & $\begin{array}{l}\text { Immediate } \\
\text { 3-6months } \\
\text { 12-15months }\end{array}$ & $\begin{array}{l}0.05 \\
0.02 \\
0.02\end{array}$ \\
\hline $\begin{array}{l}\text { Intention to reduce sugar } \\
\text { intake }\end{array}$ & $\begin{array}{l}5 \text { point Agreement scale } \\
1 \text { strongly disagree - } 5 \\
\text { strongly agree }\end{array}$ & Cambridge, East England, UK & ADDITION (Paddison et al., 2009) & $\begin{array}{l}\text { Immediate } \\
\text { 3-6months } \\
\text { 12-15months }\end{array}$ & $\begin{array}{l}0.04 \\
0.02 \\
0.02 \\
\end{array}$ \\
\hline
\end{tabular}

*Indicates $p<0.05$

Positive effect size indicates negative screen group $>$ control (unscreened group)

Weight

\begin{tabular}{|l|l|l|l|l|}
\hline Measure & $\begin{array}{l}\text { Description of } \\
\text { measure }\end{array}$ & Condition and population & Study & Time frame \\
\hline Weight & Self-reported weight & $\begin{array}{l}\text { Colorectal cancer screening } \\
\text { Telemark and Oslo, Norway }\end{array}$ & $\begin{array}{l}\text { NORCCAP(Larsen et } \\
\text { al., 2007) }\end{array}$ & 3 yrs \\
\hline Weight & Self-reported weight & $\begin{array}{l}\text { Colorectal cancer screening } \\
\text { Telemark and Oslo, Norway }\end{array}$ & $\begin{array}{l}\text { NORCCAP(Berstard al 2014) } \\
\text { et al }\end{array}$ & 11 years \\
\hline
\end{tabular}

*Indicates $p<0.05$

Positive effect size indicates negative screen group $>$ control (unscreened group) 


\begin{tabular}{|c|c|c|c|c|c|}
\hline Body mass index & $\begin{array}{l}\text { Self-reported height } \\
\text { and weight }\end{array}$ & $\begin{array}{l}\text { Diabetes screening } \\
\text { Netherlands }\end{array}$ & (Willems et al., 2013) & 4 yrs & -0.11 \\
\hline Body mass index & $\begin{array}{l}\text { Self-reported height } \\
\text { and weight }\end{array}$ & $\begin{array}{l}\text { Colorectal cancer screening } \\
\text { Telemark and Oslo, Norway }\end{array}$ & NORCCAP(Larsen et al., 2007) & 3 yrs & $0.05^{*}$ \\
\hline
\end{tabular}

*Indicates $p<0.05$, Positive effect size indicates negative screen group > control (unscreened group)

\section{Waist circumference}

\begin{tabular}{|c|c|c|c|c|c|}
\hline Measure & Description of measure & Condition and population & Study & $\begin{array}{l}\text { Time } \\
\text { frame }\end{array}$ & Effect size \\
\hline Waist circumference & self measured & $\begin{array}{l}\text { Diabetes screening } \\
\text { Netherlands }\end{array}$ & (Willems et al., 2013) & 4 yrs & $\begin{array}{l}-0.05 \\
-0.11\end{array}$ \\
\hline
\end{tabular}

*Indicates $p<0.05$, Positive effect size indicates negative screen group $>$ control (unscreened group)

\section{Physical activity}

\begin{tabular}{|c|c|c|c|c|c|}
\hline Measure & Description of measure & Condition and population & Study & Time frame & $\begin{array}{l}\text { Effect size (Or odds } \\
\text { ratio where } \\
\text { appropriate) }\end{array}$ \\
\hline Physical activity & Increased or not since screening & $\begin{array}{l}\text { Diabetes screening } \\
\text { Netherlands }\end{array}$ & $\begin{array}{l}\text { (Willems et al., } \\
\text { 2013) }\end{array}$ & 4 yrs & Odds ratio 0.82 \\
\hline Physical activity & $\begin{array}{l}\text { Frequency of physical activity either } \\
\text { with or without sweating }\end{array}$ & $\begin{array}{l}\text { Colorectal cancer screening } \\
\text { Telemark and Oslo, Norway }\end{array}$ & $\begin{array}{l}\text { NORCCAP(Larsen } \\
\text { et al., 2007) }\end{array}$ & 3 yrs & $-0.17^{*}$ \\
\hline Physical activity & Undertaking 20 mins or more per day & $\begin{array}{l}\text { Colorectal cancer screening } \\
\text { Telemark and Oslo, Norway }\end{array}$ & $\begin{array}{l}\text { NORCCAP(Berstard } \\
\text { et al 2014) }\end{array}$ & 11years & -0.15 \\
\hline $\begin{array}{l}\text { Intention to increase } \\
\text { Physical activity }\end{array}$ & $\begin{array}{l}5 \text { point Agreement scale } 1 \text { strongly } \\
\text { disagree }-5 \text { strongly agree }\end{array}$ & $\begin{array}{l}\text { Diabetes Screening } \\
\text { Cambridge, east England, } \\
\text { UK }\end{array}$ & $\begin{array}{l}\text { ADDITION } \\
\text { (Paddison et al., } \\
\text { 2009) }\end{array}$ & $\begin{array}{l}\text { Immediate } \\
\text { 3-6months } \\
12-15 \mathrm{~ms}\end{array}$ & $\begin{array}{l}0.11 \\
-0.05 \\
0.02\end{array}$ \\
\hline
\end{tabular}

*Indicates $p<0.05$, Positive effect size indicates negative screen group $>$ control (unscreened group). 


\section{Appendix 4 PRISMA checklist}

\begin{tabular}{|c|c|c|c|}
\hline Section/topic & $\#$ & Checklist item & $\begin{array}{l}\text { Reported } \\
\text { on page } \\
\#\end{array}$ \\
\hline \multicolumn{4}{|l|}{ 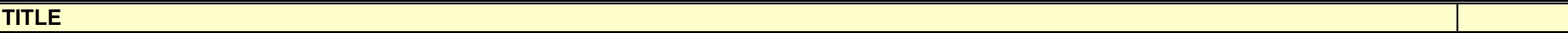 } \\
\hline Title & 1 & Identify the report as a systematic review, meta-analysis, or both. & 1 \\
\hline \multicolumn{4}{|l|}{ ABSTRACT } \\
\hline $\begin{array}{l}\text { Structured } \\
\text { summary }\end{array}$ & 2 & $\begin{array}{l}\text { Provide a structured summary including, as applicable: background; objectives; data sources; study eligibility criteria, participants, and } \\
\text { interventions; study appraisal and synthesis methods; results; limitations; conclusions and implications of key findings; systematic review } \\
\text { registration number. }\end{array}$ & $1-2$ \\
\hline \multicolumn{4}{|c|}{ INTRODUCTION } \\
\hline Rationale & 3 & Describe the rationale for the review in the context of what is already known. & $2-3$ \\
\hline Objectives & 4 & $\begin{array}{l}\text { Provide an explicit statement of questions being addressed with reference to participants, interventions, comparisons, outcomes, and study } \\
\text { design (PICOS). }\end{array}$ & $3-4$ \\
\hline \multicolumn{4}{|l|}{ METHODS } \\
\hline $\begin{array}{l}\text { Protocol and } \\
\text { registration }\end{array}$ & 5 & $\begin{array}{l}\text { Indicate if a review protocol exists, if and where it can be accessed (e.g., Web address), and, if available, provide registration information } \\
\text { including registration number. }\end{array}$ & $\begin{array}{l}\text { No } \\
\text { protocol }\end{array}$ \\
\hline Eligibility criteria & 6 & $\begin{array}{l}\text { Specify study characteristics (e.g., PICOS, length of follow-up) and report characteristics (e.g., years considered, language, publication status) } \\
\text { used as criteria for eligibility, giving rationale. }\end{array}$ & $3-4$ \\
\hline $\begin{array}{l}\text { Information } \\
\text { sources }\end{array}$ & 7 & $\begin{array}{l}\text { Describe all information sources (e.g., databases with dates of coverage, contact with study authors to identify additional studies) in the search } \\
\text { and date last searched. }\end{array}$ & $3-4$ \\
\hline Search & 8 & Present full electronic search strategy for at least one database, including any limits used, such that it could be repeated. & $\begin{array}{l}\text { Appendix } \\
1(\operatorname{Pg} 19)\end{array}$ \\
\hline Study selection & 9 & State the process for selecting studies (i.e., screening, eligibility, included in systematic review, and, if applicable, included in the meta-analysis). & 4 \\
\hline $\begin{array}{l}\text { Data collection } \\
\text { process }\end{array}$ & 10 & $\begin{array}{l}\text { Describe method of data extraction from reports (e.g., piloted forms, independently, in duplicate) and any processes for obtaining and confirming } \\
\text { data from investigators. }\end{array}$ & 4 \\
\hline Data items & 11 & List and define all variables for which data were sought (e.g., PICOS, funding sources) and any assumptions and simplifications made. & 3-4 \\
\hline $\begin{array}{l}\text { Risk of bias in } \\
\text { individual } \\
\text { studies }\end{array}$ & 12 & $\begin{array}{l}\text { Describe methods used for assessing risk of bias of individual studies (including specification of whether this was done at the study or outcome } \\
\text { level), and how this information is to be used in any data synthesis. }\end{array}$ & 5 \\
\hline
\end{tabular}




\begin{tabular}{|c|c|c|c|}
\hline $\begin{array}{l}\text { Summary } \\
\text { measures }\end{array}$ & 13 & State the principal summary measures (e.g., risk ratio, difference in means). & 5 \\
\hline $\begin{array}{l}\text { Synthesis of } \\
\text { results }\end{array}$ & 14 & $\begin{array}{l}\text { Describe the methods of handling data and combining results of studies, if done, including measures of consistency }\left(e . g ., I^{2}\right) \text { for each meta- } \\
\text { analysis. }\end{array}$ & 5 \\
\hline
\end{tabular}




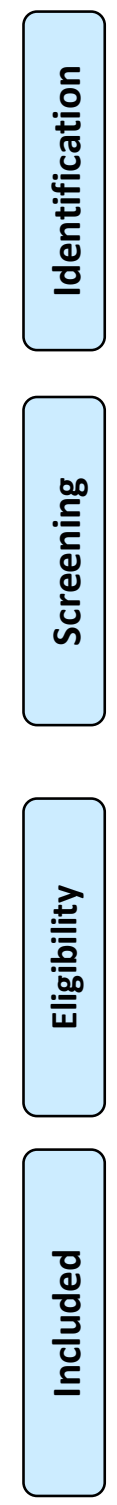

\section{Records identified through database searching \\ $(n=360)$}

Additional records identified through other sources

$(n=5)$

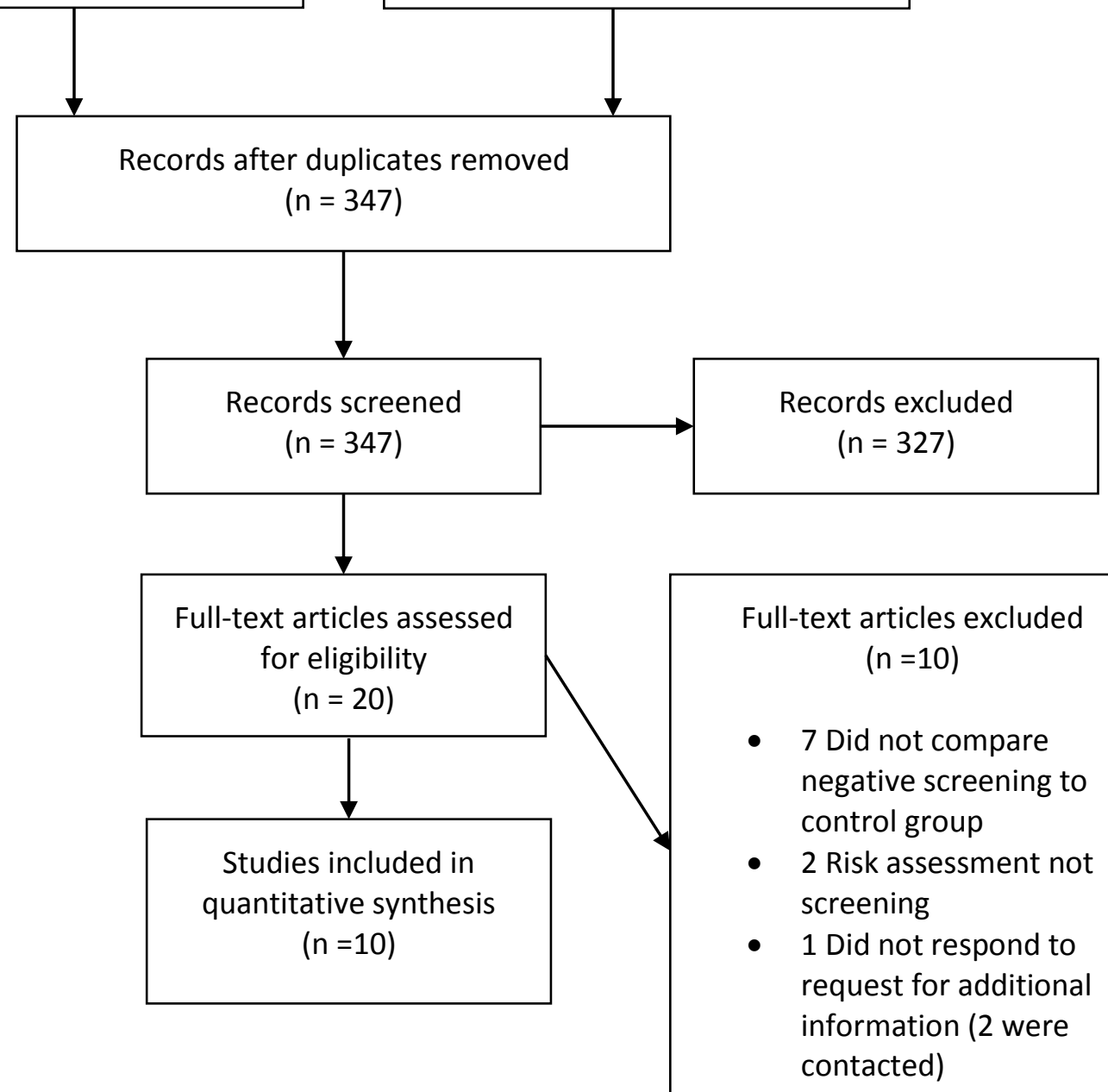

From: Moher D, Liberati A, Tetzlaff J, Altman DG, The PRISMA Group (2009). Preferred Reporting Items for Systematic Reviews and MetaAnalyses: The PRISMA Statement. PLoS Med 6(7): e1000097. doi:10.1371/journal.pmed1000097 
Table 1. Summary of the eight different studies which were included in the review

\begin{tabular}{|c|c|c|c|c|c|}
\hline Study & Condition screened for & Country & $\begin{array}{l}\text { Sample size } \\
\text { (Response rate)* }^{*}\end{array}$ & What was measured & $\begin{array}{l}\text { How long after } \\
\text { screening } \\
\text { measurement was } \\
\text { taken }\end{array}$ \\
\hline ADDITION 1,3 & Type 2 diabetes & Cambridge, East of England, UK & $\begin{array}{l}6416(33 \%) \\
1366 \text { (At 7yrs) } \\
(61 \%)\end{array}$ & $\begin{array}{l}\text { Perceived risk } \\
\text { Self rated health } \\
\text { Anxiety } \\
\text { Behaviour/intention to change }\end{array}$ & $\begin{array}{l}3-6 \text { Months } \\
12-15 \text { Months } \\
7 y e a r s\end{array}$ \\
\hline ADDITION pilot ${ }^{6}$ & Type 2 diabetes & Cambridge, East of England, UK & $290(66 \%)$ & Anxiety & 6 Weeks \\
\hline DLCST 8 & Lung cancer & Copenhagen, Denmark & $3931(92 \%)$ & Behaviour/Intention to change & 1 Year \\
\hline MASS $^{4}$ & $\begin{array}{l}\text { Abdominal aortic } \\
\text { aneurysm }\end{array}$ & $\begin{array}{l}\text { Portsmouth, Southampton, } \\
\text { Winchester, and Oxford, South } \\
\text { England, UK }\end{array}$ & $1644(82 \%)$ & $\begin{array}{l}\text { Self rated health } \\
\text { Anxiety }\end{array}$ & 6 weeks \\
\hline NELSON ${ }^{9}$ & Lung cancer & Rotterdam, Netherlands & $1284(84 \%)$ & Behaviour/Intention to change & 2 years \\
\hline NORCCAP 7,10 & Colorectal cancer & Telemark and Oslo, Norway & $7143(74)$ & Behaviour/Intention to change & $\begin{array}{l}\text { 3years } \\
11 \text { years }\end{array}$ \\
\hline $\mathrm{PLCO}^{5}$ & $\begin{array}{l}\text { Prostate, lung, Colorectal } \\
\text { and Ovarian cancer } \\
\text { screening }\end{array}$ & Nation wide, USA & $278(85 \%)$ & Self rated health & 1years \\
\hline $\begin{array}{l}\text { Willems et al., } \\
(2013)^{2}\end{array}$ & Type 2 diabetes & South west Netherlands & $14012(72 \%)$ & $\begin{array}{l}\text { Perceived risk } \\
\text { Self rated health } \\
\text { Anxiety } \\
\text { Behaviour/intention to change }\end{array}$ & 4 years \\
\hline
\end{tabular}


effect sizes or odds ratio for each outcome.

\begin{tabular}{|c|c|c|c|c|c|c|}
\hline Outcome measured & Number of tests & $\begin{array}{l}\text { Number of } \\
\text { significant } \\
\text { results }\end{array}$ & $\begin{array}{l}\text { Lowest } \\
\text { effect } \\
\text { size }\end{array}$ & $\begin{array}{l}\text { Highest } \\
\text { effect } \\
\text { size }\end{array}$ & $\begin{array}{l}\text { Lowest } \\
\text { odds } \\
\text { ratio }\end{array}$ & $\begin{array}{l}\text { Highest } \\
\text { odds } \\
\text { ratio }\end{array}$ \\
\hline Perceived risk & 7 & 2 & -0.16 & -0.01 & $N / A$ & $N / A$ \\
\hline Absolute risk ${ }^{1}$ & 3 & 0 & -0.3 & -0.01 & N/A & N/A \\
\hline Comparative risk ${ }^{1,2}$ & 4 & 2 & -0.16 & -0.02 & $N / A$ & N/A \\
\hline Self-rated heath & 11 & 0 & -0.55 & 0.14 & 1.1 & 1.1 \\
\hline Self-rated health scale ${ }^{1,3}$ & 4 & 0 & -0.06 & 0.04 & 1.1 & 1.1 \\
\hline EuroQol visual acuity score 4 & 1 & 0 & $N / A$ & 0.05 & $N / A$ & $N / A$ \\
\hline SF-36 Physical health ${ }^{4,5}$ & 3 & 0 & -0.27 & 0.14 & N/A & $N / A$ \\
\hline SF-36 Mental health ${ }^{4,5}$ & 3 & 0 & -0.55 & 0.04 & $N / A$ & $N / A$ \\
\hline Anxiety or worry & 9 & 2 & -0.22 & 0.06 & $N / A$ & $N / A$ \\
\hline Worry about disease 2,3 & 4 & 1 & -0.22 & 0.01 & $N / A$ & $N / A$ \\
\hline State trait anxiety $2,4,6$ & 5 & 1 & -0.09 & 0.15 & N/A & N/A \\
\hline $\begin{array}{l}\text { Behaviour and intention to } \\
\text { change behaviour }\end{array}$ & 28 & 5 & -0.11 & 0.17 & 0.74 & 1.1 \\
\hline Smoking $2,7,8,910$ & 6 & 1 & 0.02 & 0.07 & 0.74 & 1.1 \\
\hline Physical activity ${ }^{1,2,7,10}$ & 6 & 1 & -0.15 & 0.11 & N/A & 0.82 \\
\hline Diet quality ${ }^{1,7,10}$ & 10 & 1 & -0.08 & 0.05 & N/A & N/A \\
\hline Weight 7,10 & 2 & 1 & 0.07 & 0.17 & N/A & N/A \\
\hline $\mathrm{BMI}^{2,7}$ & 2 & 1 & -0.11 & 0.05 & N/A & N/A \\
\hline Waist circumference ${ }^{2}$ & $\begin{array}{l}2 \text { (from same } \\
\text { study but men } \\
\text { and women } \\
\text { reported } \\
\text { separately) }\end{array}$ & 0 & -0.11 & -0.05 & N/A & $N / A$ \\
\hline
\end{tabular}

Bold text indicates a summary of all measurements used to measure each outcome.

Positive effect size indicates negative screening test result group > control group

${ }^{1}$ (Paddison et al., 2009), ' (Willems, Otto, Klijs, \& de Koning, 2013), ${ }^{3}$ (Eborall et al., 2007), ${ }^{4}$ (Scott, 2002), ${ }^{5}$ (Taylor, Shelby, Gelmann, \& McGuire, 2004), ${ }^{6}$ (Park, Simmons, Prevost, \& Griffin, 2008), ${ }^{7}$ (Larsen, Grotmol, Almendingen, \& Hoff, 2007),

${ }^{8}$ (Ashraf et al., 2008), ${ }^{9}$ (van der Aalst, van den Bergh, Willemsen, de Koning, \& van Klaveren, 2010), ${ }^{10}$ (Berstad et al., 2014) 